\title{
Mediation Role of Organizational Support in the Effect of Organizational Climate on Turnover Intention in Hotels ${ }^{1}$
}

\author{
Şükran ÖKTEM \\ Social Sciences Vocational School, Başkent University, Turkey sukran@baskent.edu.tr \\ Menekşe ÖZTOPRAK \\ Social Sciences Vocational School, Başkent University, Turkey tarhan@baskent.edu.tr
}

\begin{abstract}
Employee participation is crucial to the success of hotels. The performance of the employees of the organization may vary according to their personalities and may be positively or negatively affected by the organizational climate. This study aims to obtain information on whether organizational support plays a role in the effect of organizational climate on employee turnover intention. For this purpose, data were collected from 300 people working in 4 and 5 star hotel establishments. Structural Equation Model was used to test hypotheses. The results showed that organizational climate has a negative effect on turnover intention and that organizational support positively affects organizational support negatively on turnover intention.
\end{abstract}

Keywords: Hotel, Organizational Support, Organizational Climate, Turnover Intention

\section{Introduction}

The contribution of employees is crucial in the success of the hotels, and organizational research should be among the priorities of the researchers. The performances of the employees constituting the organization may vary according to their personalities, and may also be influenced positively or negatively by the organizational climate. Decisions and practices taken by the management form the basis of the organizational climate (Altaş \& Kuzu, 2013). Organizational trust also occurs when the organizational climate creates a positive atmosphere. So performance is affected positively and productivity increases in business (Brondino \&Pasini, 2012). A negative organizational climate can cause the employee to think about the turnover. As a result, a support may be needed to prevent the turnover intent, which is called an organizational trust that anticipation will take place in order to be fair and ethical to the employees of the employer, while also increasing the motivation of the employee (Akgündüz \& Güzel, 2014). The intention to separate from the work that emerged due to the negative organizational climate and which often turns out to be an act of intention is to be dissatisfied with the organizational environment in which the work is being held and with the wages and awards it receives and to think about leaving the workplace as a result of its inability to use its existing potential (Akyüz \& Yılmaz, 2015). Organizational support shows the quality of the relationship between the employee and the organization. When employees think that organizations value themselves, they create a positive atmosphere (Demirel, 2013).

1Study has been presented at the 9th World Conference for Graduate Research in Tourism, Hospitality \& Leisure to be held in Cartagena, Spain, 6/6/2017 - 6/11/2017. 
The main purpose of this study is; how employees in hotel businesses perceive the organizational climate in the workplace and whether there is an intermediary effect of organizational support on the turnover intention as a result of this perception.

\section{Literature Review}

\section{Organizational Climate}

Organizational climate is a context in which, according to different perspectives of employees, the psychological perceptions that result from the development of people-oriented, business or relationship-focused (Colley et al. 2013), (Karatas, 2015). The measurable characteristics of the working environment affect employees' motivation and behavior on collective perceptions (Datta \& Singh, 2018). The organizational climate was first described by Taguiri in 1963 (Asif, 2011). Psychological perceptions that are called politeness, sincerity, rewarding, direction are positively affecting the organizational climate (Güzeler \& Dedeoğlu, 2016). Communication with customers in the tourism sector is more and organizational climate that affecting the behavior of employees and providing a positive impression of business management is the main factor (Eröz, 2014). The organizational climate was first described by Taguiri in 1963 and it was emphasized in the 1970s and 1990s that the definition of the academic field in different ways should have similar perceptions in hierarchical levels of work within a particular subsystem or organization (Asif, 2011).Generally, when a high-level creative organizational climate is created in the business, employees are also eager to share their knowledge and are eager to share information (Chen \& Huang, 2007). A safe climate increases change motivation and allows employees to innovate (Fainshmidt \& Frazier, 2016), Innovative business behavior develops when employees are given freedom and autonomy. There are studies showing significant relationships between individual innovation and autonomy and organizational climate dimensions in the literature (Shanker et al, 2017). And the organization is a source of help when employees face stressful or challenging situations (Shih et al, 2014).

\section{Turnover Intention}

The turnover intention is to leave the job for reasons such as not being satisfied with the job environment in which the job is taking place, being unhappy, and considering other job options. If management can not provide a good working environment, they intend to turnover if they are doing practices that will detract from their desire for work despite their adequate qualifications. In the field of literature, the idea of leaving the work because of the negative perception of the organizational climate by the occupations prevails. However, the turnover intention may also be related to the psychological structure of the employee, if they do not fit their qualifications, have not found a job they want to work on, and are forced to continue their life, they may consider leaving the job even if the organizational climate is perfect (Güzel, 2002). Apart from these, there is a belief that there is a better wage for another job, better working conditions, problems with staff in a horizontal and vertical position, and a sense of better management in another workplace. Turnover intention may vary depending on whether business conditions in different sectors are positive or negative, and there are studies supporting this idea in the literature (Van der Heijden et al, 2018). Employee turnover, in such industries as the casino industry, can be given as an example (Li et al, 2017). In order to reduce the turnover intention of employees to leave the hotels and to ensure that employees work adaptation in the work environment, human resources specialists should consider developing and implementing regularly planned and long-term training programs (Li et al, 2019). 


\section{Organizational Support}

Through the positive climate in the organization, employees are happy in the business environment, ensuring social rights and security, creating the perception that the opportunities provided will be continuous (Özdevecioğlu, 2003). Individual differences and self-confidence play a role in making employees happy in the work environment. In order to increase their selfconfidence, individuals will tend to identify with groups perceived as positive to identify themselves in certain settings (Shen et al, 2014). Employees will be loyal to their business if they feel the support of the management, will perform better and will not consider leaving their jobs. The perception of organizational support should create a sense of respect, loyalty, and approval for employees. Organizational support, often in the form of praise, reward, and appreciation, increases management confidence in employees, thereby increasing the reputation of the business (Akgündüz \& Sanl, 2017). Organizational support perceived by employees can be considered as a kind of organizational resource. Organizational support, perceived as a complementary resource to the employee, can create a range of positive emotional perceptions and experiences in the workplace (Wen et al, 2019). The labor-intensive hospitality industry can often result in a stressful organizational climate as a result of adverse working conditions, so organizational support is important (Xiong \& King, 2018). The employer expects loyalty and high performance from its employees, while the employees expects a secure environment and organizational support. Organizational support perceived by the employee can be examined in five subdimensions that should be taken into consideration by the enterprises; welfare of employees, personal goals of employees, employees' contributions to the business, to help employees in their career / professional development and to be proud of their efforts (Ming-Chu \& Meng-Hsiu, 2015). When employees meet expectations, their performance increases (Aydın \& Tüzün, 2019). The organizational support effect is beneficial as a result of employees being nervous due to the working environment (Kim et al, 2017).

\section{Methodology}

Models and hypothesises which are formed according to the results of the literature search and optimal to the aim of the research are shown below:

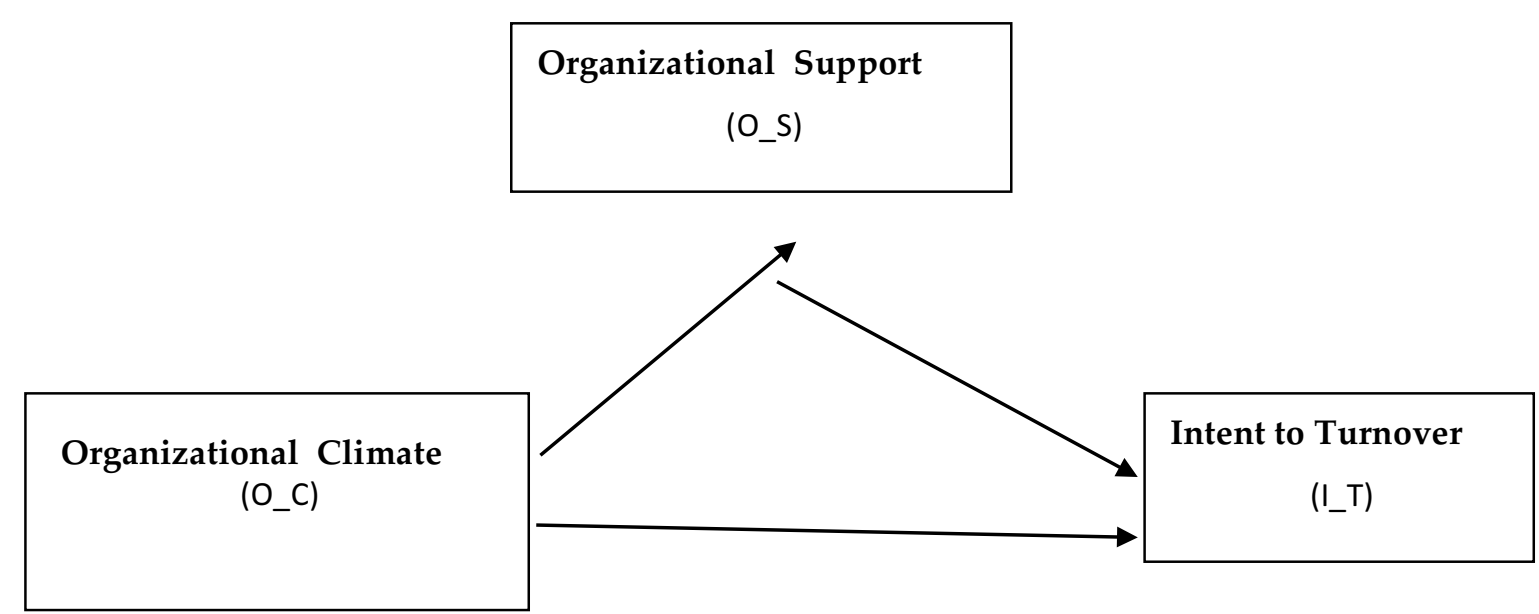

Figure 1. Research Model

Hypothesis 1:Organizational climate affects intent to turnover negatively.

Hypothesis 2:Organizational climate affects organizational support positively.

Hypothesis 3:Organizational support affects intent to turnover negatively. 
Hypothesis 4: There is a mediation role of organizational support in a relation between organizational climate and intent to turnover.

In order to measure organizational climate variable, a scale was developed by Türen et al. (2014) and to measure intent to turnover variable, a scale was developed by Scott et al. (1999) and to determine the level of organizational support perceived by the employees, the scale made by Turunç \& Çelik (2010). The universe of this work consists of 4-5 star hotel employees. The sample size required for the study was determined as 384 with a formula of $n=\pi(1-\pi) /(\mathrm{e} / \mathrm{Z})$ and $95 \%$ confidence interval e $=5 \%$ error (Kurtuluş, 1998), 300 questionnaires has returned. In order to test the validity of the scales, confirmatory factor analysis has been performed by AMOS 22 program. Since compliance measurement values produced by the model created for the scale of the validity of the tests is not within acceptable limits therefore modifications suggested by the program have been made.

Adaptive values have been produced by the measurement models are within the limits of acceptable so one factor that all variable structures were confirmed. In order to determine the reliability of the scale cronbach alpha coefficients were calculated with SPSS 22 program. Coefficients was realized as 0.96 on the organizational climate scale; 0.81 on the organizational support scale and 0.82 on the turnover intention scale.

This score shows that they are reliable quality scale.

\section{Results}

\section{Demographic Features of the Attendee}

$\% 48$ of the attendee are female $(\mathrm{N}=144) ; \% 52$ of them are male $(\mathrm{N}=156) . \% 61$ is married $(\mathrm{N}=183)$; $\% 39$ is single $(\mathrm{N}=117)$. \%23,7 is between 31-35 ages $(\mathrm{N}=71) ; \% 48,3$ is graduated from high school $(\mathrm{N}=145), \% 70$ has between 1001-2000 TL income $(\mathrm{N}=210) . \% 42,3$ have been in the same workplace for between 0-3 years ( $\mathrm{N}=127)$, \%35 have been working in this sector for 11 years or more $(\mathrm{N}=105)$.

\section{Structural Equation Modeling}

Structural equation modeling formed in order to test the hypothesizes of the research is shown on the Figure 2.

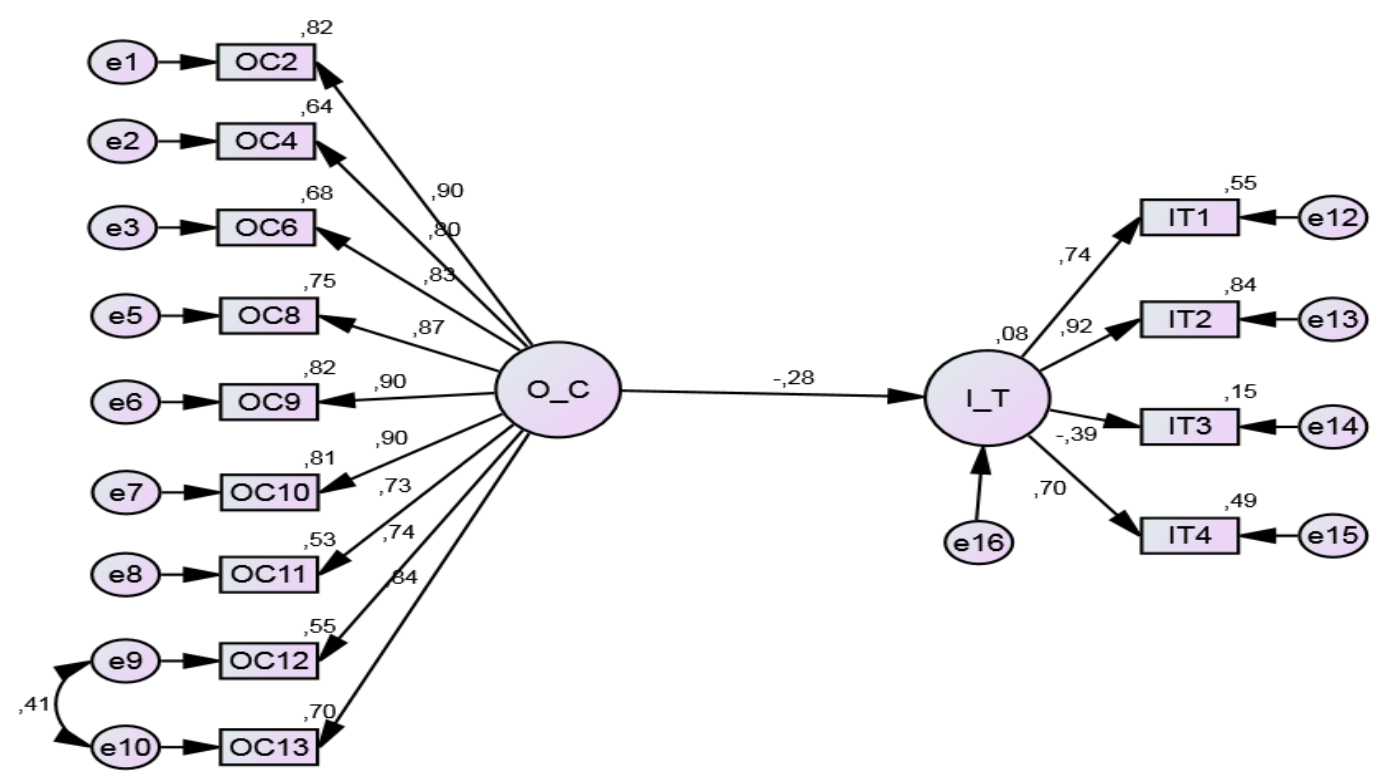

Figure 2 Structural Equation Modeling 
Figure 2 shows adaptive values of the structural model is not in compliance with acceptable limits, the results of modification by suggested of the program 2 expression was removed from the organizational climate scale. Modification results adaptive value ( $X^{2}: 253,364$; df:63; $\mathrm{X}^{2} / \mathrm{df}: 4,022$; GFI:0,90; CFI:0,95; RMSEA:0,080) were observed to be within acceptable limits. Organizational climate affect turnover intention $(\beta=-0,28 ; \mathrm{p}<0,05)$. According to this result of the research 1 hypothesis is supported.

\section{Testing of Intermediary Effect by Structural Equation Model}

The three-step method proposed by Baron and Kenny (1986) was used to determine the intermediary effect. According to the authors first stage; independent variable affects dependent variable, second stage; independent variable affects mediating variable, the third and final stage; when the mediating variable is included in the first-order model mediating variable affects dependent variables while the independent variable has less effect on the dependent variable. The effects of the independent variable on the dependent variable are shown in the first stage (Figure 2) the structural equation model for the second and third stage test is shown in Figure 3.

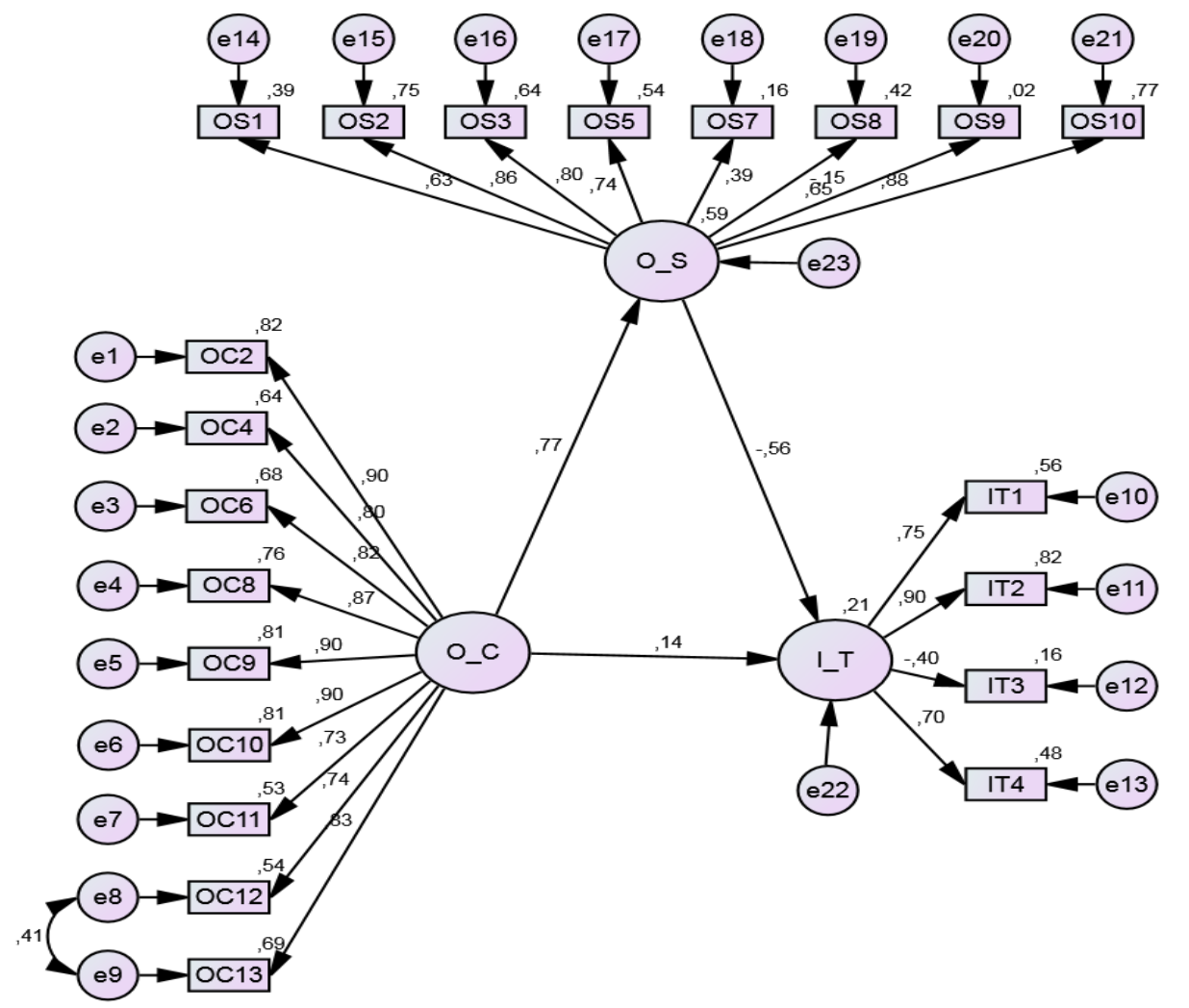

Figure 3. Structural Equation Model for mediating effect

It was observed that the concordance value of the structural model shown in Figure 3 ( $X^{2}: 905,390$; df: 185; $X^{2} /$ df: 4,894; GFI: 0,87; CFI: 0,95; RMSEA: 0,079) is within acceptable limits. Organizational climate has a significant effect on organizational support $(\beta=0.77, p<0.05)$. So the research hypothesis of number 2 was supported. The third stage was tested since Baron and Kenny (1986) provided the second stage. Hypothesis 3 of the research was also supported because of the observed effects of organizational support $(\beta=-0,56 ; p<0,05)$ on turnover intention.

When the mediating variable is included to model because of the fact that the significant effects of the independent variable on the dependent variable that is left out is determined the third step proposed by Baron and Kenny (1986) are also provided. The full mediation effect of 
organizational support can be said because the meaningful effect of the organizational climate on the turnover intention has ceased to exist. For this reason, the hypothesis \# 4 of the research was supported. When the $\mathrm{R}^{2}$ values obtained from the model are examined, it is seen that $59 \%$ of the organizational support is explained by the organizational climate and $21 \%$ of the turnover intention by the organizational climate and organizational support variables.

\section{Conclusion and Implications}

Organizational climate and organizational trust are important in terms of employee performance in hotels as in all enterprises. The positive or negative attitude of the management affects the employee due to the fact that the communication with the customer is higher than the other sectors. When this effect is positive, communication with the customer is also positive, and if the effect is negative, the turnover intention may arise. In this study research, which whether organizational climate has an influence on the turnover intention of employees and also whether organizational support has mediating feature in the data obtained as a result of the questionnaire applied in four- and five-star hotel enterprises whether is supported the hypotheses and it was seen that the results obtained is supported the four hypotheses. These results show that there is a favorable organizational climate in the hotel enterprises in which the study is conducted and therefore there is no turnover intention and that organizational support parallel to the positive organizational climate plays an intermediary role between these two variables.

\section{Acknowledgments}

In this study, we thank to our colleague Asst. Prof. Dr. Erkan YILDIZ.

\section{References}

Akgündüz; Y. \& Güzel, T. (2014). Örgütsel adalet ile örgütsel bağlllık arasındaki ilişkide örgütsel güvenin aracılık etkisi, Anadolu Üniversitesi Sosyal Bilimler Dergisi, Cilt/Vol.:14 Sayı/No: 3 (1-18).

Akgündüz, Y. \& Sanlı, S. C. (2017). The effect of employee advocacy and perceived organizational support on job embedded ness and turnover intention in hotels, Journal of Hospitality and Tourism Management, 31 (2017) 118e125.

Akyüz, M. \&Yılmaz, F. D. (2015). Konaklama işletmelerinde örgütsel özdeşleşme ve örgütsel iletişimin işgörenlerin işten ayrılma niyetine etkisi, Kastamonu Üniversitesi İktisadi ve İdari Bilimler Fakültesi Dergisi, Temmuz 2015, Sayı:8.

Altaş, S. S. \& Kuzu, A. (2013). Örgütsel etik, örgütsel güven ve bireysel iş performansı arasındaki ilişki: okul öncesi öğretmenleri üzerinde bir araştırma, Elektronik Mesleki Gelişim ve Araştırmalar Dergisi, 1(2), 29-41.

Asif, F. (2011). Estimating the impact of Denison's (1996), What is the difference between organizational culture and organizational climate? A native's point of view on a decade of paradigm wars, Journal of Business Research, 64 (2011) 454-459.

Aydın, E. \& Tüzün, İ. K. (2019): Organizational support sources and job performance relations: what about occupational commitment?, Anatolia, DOI: 10.1080/13032917.2019.1597740

Baron, R.M. \& Kenny, D.A. (1986). The Moderator-MediatorVariableDistinction in SocialPsychologyResearch: Conceptual, Strategic and Statistical Considerations. Journal of Personallity and Social Psychology, Vol.51, No.6, 1986, s. 1173-1182. 
Brondino, M.; Silva, S. A., Pasini, M. (2012). Multi level approach to organizational and group safety climate and safety performance: co-workers as the missing link, Safety Science,50(9): 1847-1856.

Chen, C-J.; \&Huang, J-W. (2007). How organizaational climate and structure affect knowledge management- the social interaction perspective, International Journal of Information Management 27 (2007) 104-118.

Colley, S. K., Lincolne, J., Neal, A. (2013). An examination of the relationship amongst profiles of perceived organizational values, safety climate and safety outcomes, Safety Science,51(1): 69-76.

Datta, A. \& Singh, R. (2018). Determining the dimensions of organizational climate perceived by the hotel employees, Journal of Hospitality and Tourism Management, 36, 40-48.

Demirel, E. T. (2013). Mesleki stresin iş tatminine etkisi: örgütsel desteğin aracılık rolü, Niğge Üniversitesi IIIBF Dergisi, 2013, Cilt: 6, Sayı: 1, s. 220-241.

Eröz, S. S. (2014). Otel işletmelerinde örgüt iklimi ve duygusal emek ilişkisi: Trakya bölgesinde bir araştırma, HAK-İş Uluslararası Emek ve Toplum Dergisi @ Cilt: 3, Yıl: 3, Sayı: 7 (2014/3).

Fainshmidt, S. \& Frazier, M. L. (2016). What facilitates dynamic capabilities? The role of organizational climate for trust, Long Range Planning (2016), doi: 10.1016/j.1rp.2016.05.005

Güzel, E. (2002). Otel işletmelerinde işgören devrinin nedenleri: Kuşadası ve İzmir'deki dört ve beş yıldızlı otel işletmelerinde bir alan araştırması, T.C. Adnan Menderes Üniversitesi Sosyal Bilimler Enstitüsü, Trz - yl - $2002-004$.

Güzeler, A. K. \& Dedeoğlu, A. Ö. (2016). Üniversitelerde inovasyon ekosisteminin geliştirilmesinde örgüt iklimi, örgüt kültürü ve örgüt yapısının inovatif davranış üzerindeki etkisi: Ege Üniversitesi örneği, Ege Stratejik Araştırmalar Dergisi Cilt 7, Özel Sayı, 2016.

Karataş, A. (2015). Örgütsel iklimin örgütsel vatandaşlık davranışına etkisi. Bursa ilinde bir araştırma, Çukurova Üniversitesi İiBF Dergisi, Cilt:19. Sayı:1.Haziran 2015 ss.47-58.

Kim, H.J.; Hur, W., M.; Moon, T., W.; Jun, J., K. (2017). Is all support equal? The moderating effects of supervisor, coworker, and organizational support on the link between emotional labor and job performance, BRQ Business Research Quarterly (2017) 20, 124---136.

Kurtuluş, K. (1998). Pazarlama Araştırmaları, 8. Basım, Avcıol Basım Yayım, i̇stanbul.

Li, J.; Kim, W. G., Zhao, X. (2017). Multilevel model of management support and casino employee turnover intention, Tourism Management 59 (2017) 193-204.

Li, J.; Bonn, M. A.; Ye, B. H. (2019). Hotel employee's artificial intelligence and robotics awareness and its impact on turnover intention: The moderating roles of perceived organizational support and competitive psychological climate, Tourism Management 73 (2019) 172-181.

Ming-Chu, Y.; Meng-Hsiu, L. (2015). Unlocking the black box: Exploring the link between perceive organizational support and resistance to change, Asia Pacific Management Review 20 (2015) $177 \mathrm{e} 183$.

Özdevecioğlu, M. (2003). Algılanan örgütsel destek ile örgütsel bağlllık arasındaki ilişkilerin belirlenmesine yönelik bir araştırma, D.E.Ü.İ.I.B.F.Dergisi Cilt:18 Sayı:2, Yı1:2003, ss:113 130. 
Scott, C.R.;Connaughton, S.L.; Diaz-Saenz, H.R.; Maguire,K.,Ramirez, R.; Richardson, B., Shaw, S. P., Morgan, D. (1999). The impacts of communication and multiple identifications on intent to leave, Management Communication Quarterly, 12(3): 400-435.

Shanker, R.; Bhanugopan, R.; Heijden, B.; Farrell, M. (2017). Organizational climate for innovation and organizational performance: The mediating effect of innovative work behavior, Journal of Vocational Behavior, 100, 67-77.

Shen, Y.; Jackson, T.; Ding, C; Yuan, D.; Zhao, L.; Dou; Y.; Zhang, Q. (2014). Linking perceived organizational support with employee work outcomes in a Chinese context: Organizational identification as a mediator, European Management Journal 32 (2014) 406412.

Shih, S-P.; Lie, T.; Klein, G.; Jiang, J. J. (2014). Information technology customer aggression: the importance of an organizational climate of support, Information $\mathcal{E}$ Management 51 (2014) 670-678.

Turunç, Ö. \& Çelik, M. (2010).Çalışanların algıladıkları örgütsel destek ve iş stresinin örgütsel özdeşleşme ve iş performansina etkisi, Celal Bayar Üniversitesi İ.I.B.F. Yönetim ve Ekonomi Dergisi, 17, (2), 183-206.

Türen, U.; Gökmen, Y.; Tokmak, İ. Bekmezci, M. (2014). Güvenlik iklimi ölçeğinin geçerlilik ve güvenilirlik çalışması, Süleyman Demirel Üniversitesi İktisadi ve İdari Bilimler Fakültesi Dergisi. 19 (4): 171-190.

Van der Heijden, B. I. J. M.; Peeters, M. C. W.; Blanc, P. M. L.; Van Breukelen, J. W. M. (2018). Job characteristics and experience as predictors of occupational turnover intention and occupational turnover in the European nursing sector, Journal of Vocational Behavior 108 (2018) 108-120.

Wen, J.; Huang, S.; Hou, P. ( 2019). Emotional intelligence, emotional labor, perceived organizational support, and job satisfaction: A moderated mediation model, International Journal of Hospitality Management 81 (2019) 120-130.

Xiong, L. \& King, C. (2018). Too much of a good thing? Examining how proactive personality affects employee brand performance under formal and informal organizational support, International Journal of Hospitality Management 68 (2018) 12-22. 